\title{
Ask a Librarian LIVE
}

\section{Specialist and broad-based reference capacities expanded by new software}

by Susan Patrick and Cathy Matthews

$\mathrm{N}$ ew technology has enabled the development of the virtual reference desk, through which effective online, real-time interactive communication between librarian and patron can take place anywhere.

In September 2001, the Ryerson University Library in Toronto became one of the first university libraries in Canada to launch a real-time chat reference service-Ask a Librarian LIVE. This initiative is linked to the library's overall strategy of acquiring resources and developing services to address the needs of students and faculty who access the library through lab, office, and home computer systems connected to the Internet. The introduction of this service will enable library users to communicate, via real-time chat, with a Ryerson librarian while engaged in research online.

Funded in part through a grant proposal submitted to the McConnell Foundation' by a group of Ryerson librarians, Ask a Librarian LIVE uses software developed by eGain Communications Corporation and distributed through Library Systems and Services Virtual Reference Service.

The cobrowsing capabilities of the software enable users and librarians to follow each other's progress through a database or Web site. Librarians are able to "push" screens, documents, and PowerPoint instructional modules to users in real time.

\section{If it's nighttime, it must be Australia}

The domination of the Internet in reference work and the proliferation of Web-based academic databases have led to the development of similar profiles for virtual reference collections in university libraries around the world. Anecdotal evidence suggests that academic reference librarians with a good knowledge of a range of international databases and other Web-based resources would feel right at home slipping into the reference desk of other university libraries, particularly where there is a good institutional "fit." The same concept applies to the virtual reference desk.

In many university communities, there is not only a desire, but a demand, for $24 / 7$ virtual reference service to complement the $24 / 7$ catalog and database access offered by most university libraries. Most libraries do not have the staff to provide this service on their own. This demand has led to the idea of international partnerships in different time zones.

The time difference between Toronto and Australia (Australia is 14 to 15 hours ahead) makes Australian libraries ideal partners for the Ryerson Library in providing nighttime reference in both countries.

The Ryerson Library is currently investigating the possibilities of partnerships with Australian university libraries for future phases

\section{About the authors}


of the virtual reference project. In May 2001, Susan Patrick, distance education liaison librarian, visited Australia as part of her professional leave. Her mission was to demonstrate Ask a Librarian LIVE, in its trial stage, through interactive reference interviews with a librarian at Ryerson, and to discuss potential partnerships.

At RMIT University Library in Melbourne and University of Queensland Library in Brisbane, Patrick demonstrated the service with Ryerson's technical support and systems librarian, Bob Jackson, who was online in Toronto.

The sessions began with Jackson in the librarian's seat and Patrick logged in as a patron asking reference questions. Roles were then reversed so the audiences could see the software functioning from the librarian's perspective. A subsequent virtual demonstration from Toronto was done for the University of Southern Queensland Library in Toowoomba. The Australian librarians showed a strong interest in the potential of the service, and Ryerson Library will continue to communicate with them as we proceed through the trial and evaluation phases of this pilot project.

\section{Specialist applications for global networks}

While the objective of the Ryerson and Australia partnership is to support broad-based, cross-disciplinary service, virtual reference software can also be used effectively by specialist networks.

In May 2001, Ryerson's chief librarian, Cathy Matthews, demonstrated a real-time reference exchange (again with the help of Bob Jackson in Toronto) at the 6th Meeting of the World Criminal Justice Libraries Network (WCJLN) in Zutphen, the Netherlands. Specialist libraries and information services, which serve academic communities or government agencies, share common platforms of information, an increasing amount of which is in public domain digital format, thus enabling specialist groups such as WCJLN to serve each other's constituents in true network fashion.

While much of the literature on virtual reference thus far has focused on broad applications across disciplines, and successful implementations have been at universities or in public library consortia, it is possible that
Anecdotal evidence suggests that academic reference librarians with a good knowledge of a range of international databases and other Web-based resources would feel right at home slipping into the reference desk of other university libraries, particularly where there is a good institutional "fit." The same concept applies to the virtual reference desk.

many specialized networks can benefit from this new software.

\section{Note}

1. Librarians are welcome to contact Diane Granfield, e-mail: dgranfie@ryerson.ca, at Ryerson University Library, regarding the McConnell-funded pilot project. A report on the project will be published in the library literature and on our Web site in late 2002.

\section{CRRL News column editor wanted}

CERL News is looking for an editor for a new column on the theme of "Do You Want this Job?," which will feature interviews with librarians in unusual positions and highlight areas of the profession that are off the beaten track. The editor may conduct interviews him- or herself or coordinate interviews of librarians by colleagues and associates. The column is expected to run every other month (five times a year), be 1,000 words in length, and include a photograph of the interviewee.

If you would like to apply, send an email or letter outlining your interest and experience and a sample interview by May 10 to: Stephanie Orphan, editor-in-chief, CERL News, 50 E. Huron St., Chicago, IL 60611, e-mail: sorphan@ala.org.

Selected applicants will be invited to meet with the CGRL News Editorial Board at the ALA Annual Conference in Atlanta. 